\title{
B cell costimulatory molecules as potential biomarkers in HAM/TSP
}

\author{
Soraya M Menezes ${ }^{1 *}$, Daniele Decanine ${ }^{2}$, Ricardo Khouri ${ }^{1,2}$, Anne-Mieke Vandamme ${ }^{1}$, Bernardo Galvão-Castro ${ }^{3}$, \\ Johan Van Weyenbergh ${ }^{1,2}$
}

From 15th International Conference on Human Retroviruses: HTLV and Related Viruses

Leuven and Gembloux, Belgium. 5-8 June 2011

Current therapy in HAM/TSP includes antiretrovirals and immunomodulators, such as corticosteroids and interferons, with modest clinical benefit. Since there are no validated biomarkers to monitor disease severity (DS), progression or prognosis, we investigated the ex vivo expression of CD80 and CD86 as possible biomarkers, as well as the effect of IFN- $\alpha$ /beta on their in vitro expression in 16 Brazilian HAM/TSP patients and 15 healthy controls (HC). Flow cytometry quantification indicated significantly elevated expression of both CD80 and CD86 ex vivo in $\mathrm{T}(\mathrm{p}=0.044$ and $\mathrm{p}=0.0016)$ and $\mathrm{B}(\mathrm{p}=0.0003$ and $\mathrm{p}=0.0057)$ cells, as compared to HC. In B cells, the ex vivo percentage of CD80+ positively correlated to DS ( $\mathrm{p}=0.0083, \mathrm{r}=0.78)$, but not age or disease duration, while ex vivo expression of CD80 was gender-biased, being significantly higher in women $(\mathrm{p}=0.028)$. Upon in vitro culture, $\mathrm{CD} 80+(\mathrm{p}=0.037)$ and CD86+ lymphocytes significantly expand $(\mathrm{p}<0.0001)$, as compared to ex vivo levels, in patients only. In vitro treatment of patients' PBMCs with IFN-beta, but not IFN- $\alpha$ resulted in significant stimulation of B cell CD86 expression $(\mathrm{p}<0.05)$. In HC, both IFN- $\alpha$ and IFN-beta brought about a significant increase in CD86 expression $(\mathrm{p}<0.05$ and $\mathrm{p}<0.001)$. Neither IFN- $\alpha$ nor IFN-beta was able to significantly induce B cell CD80 expression in $\mathrm{HC}$ or patients. Consequently, B cell CD86/CD80 ratio was significantly increased upon stimulation with IFN-beta in both HC and patients. In conclusion, we propose novel biomarkers for possible clinical use in HAM/TSP trials: ex vivo $C D 80+B$ cells positively correlating to $D S$ and CD86+ B cells preferentially induced by IFN-beta.

*Correspondence: soru29@gmail.com

${ }^{1}$ Rega Institute, K.U. Leuven, Leuven, 3000 Belgium

Full list of author information is available at the end of the article

\section{Author details}

${ }^{1}$ Rega Institute, K.U. Leuven, Leuven, 3000 Belgium. ' ${ }^{2}$ IMI, CPqGM-FIOCRUZ, Salvador-BA, 40210-760, Brazil. 'AASP, CPqGM-FIOCRUZ, Salvador-BA, 40210760, Brazil.

Published: 6 June 2011

\section{doi:10.1186/1742-4690-8-S1-A106}

Cite this article as: Menezes et al: B cell costimulatory molecules as potential biomarkers in HAM/TSP. Retrovirology 2011 8(Suppl 1):A106.
Submit your next manuscript to BioMed Central and take full advantage of:

- Convenient online submission

- Thorough peer review

- No space constraints or color figure charges

- Immediate publication on acceptance

- Inclusion in PubMed, CAS, Scopus and Google Scholar

- Research which is freely available for redistribution
() Biomed Central
() Biomed Central

C 2011 Menezes et al; licensee BioMed Central Ltd. This is an open access article distributed under the terms of the Creative Commons Attribution License (http://creativecommons.org/licenses/by/2.0), which permits unrestricted use, distribution, and reproduction in any medium, provided the original work is properly cited. 